\title{
Sendingteorie en sendingpraktyk in die Nederduitsch Hervormde Kerk: Verlede, hede en toekoms
}

\author{
DJC van Wyk
}

\begin{abstract}
The missionary work of the Nederduitsch Hervormde Kerk van Afrika in theory and practice: in the past, present and future

In this article a short survey is given of the missionary work, both in theory and practice, of the Nederduitsch Hervormde Kerk during the last fifty years. There is also an indication that the Church has reached a crucial point which is going to require thorough rethinking and reconsideration of our missionary work.
\end{abstract}

Daar is oortuigende redes vir 'n hernude en omvattende besinning oor die kerk se sendingwerk vandag. Bosch (1979: 4) toon in sy werk 'n stuk of vyf oorsake aan vir die krisis waarin die sending en ook die Sendingwetenskap beland het: die feit dat die Konstantynse periode in die geskiedenis van die Christelike kerk verby is en daarmee ook die vanselfsprekendheid van kerk en sending; ook die Vasco da Gama-era, die tydperk waarin die Christendom 'n Europese aangeleentheid was, is vir goed verby; die weiering van jong kerke om hulp van die kerke in die Weste te ontvang (moratorium); die krimpende getal Christene in die wêreld, teen die einde van hierdie eeu waarskynlik nie meer as 16 persent van die wêreldbevolking nie; die onduidelikheid in soveel kringe oor wat sending eintlik is.

Hierby kan nog heelwat ander oorsake asook simptome van die krisis van die sending en die Sendingwetenskap gevoeg word. Aan verskeie Europese universiteite en teologiese fakulteite bestaan daar nie meer leerstoele in Sendingwetenskap nie of waar leerstoele vakant raak, word dit nie gevul nie.

As rede hiervoor word onder andere aangevoer dat die taak van die sending en die Sendingwetenskap afgehandel is.

Enorme verwarring is deel van die hedendaagse denke oor die sending. Ekumeniese teoloë gee soms uiteenlopende definisies van wat sending is. 
The chief difficulty in portraying the conciliar theology of evangelism is the abundance of the material and the inclusiveness of official pronouncements. Sometimes strong pronouncements advocating two opposing points of view have been printed - and then only one side implemented .... One must, therefore, continually ask 'what is the mainstream of the conciliar theology of mission, and what are the peripheral concerns voiced now and then to satisfy fringe groups?' (McGavran 1983: 65).

Al bogenoemde faktore bring mee dat daar vir die sending en Sendingwetenskap ' $n$ tyd van toetsing aangebreek het. Die vanselfsprekendheid waarmee die sending in die verlede gefundeer is, is eenvoudig nie meer geldend nie. Daar moet opnuut gekyk word of die grondslae en die funderinge van die verlede nog kan standhou.

Aan al hierdie faktore is die Nederduitsch Hervormde Kerk self ook blootgestel en hy kan aan dieselfde proses van toetsing van sy sendingwerk nie ontkom nie. Dié Kerk het inderdaad met sy sendingwerk by 'n kruispunt gekom. Belangrike vrae is aan die orde en dit kan lei tot belangrike koersaanpassings vir die toekoms. Daaraan word in die laaste paragrawe kortliks aandag geskenk.

In hierdie proses moet ons ook vir-onsself 'n paar kritiese vrae oor die verlede vra en daarop antwoorde probeer kry.

- Hoe is daar in die fundering van die sending binne die Nederduitsch Hervormde Kerk gebruik gemaak van die Skrif?

Wat was die doel en motiewe van die Kerk met sy sendingwerk?

Dit is van besondere betekenis dat daar in hierdie aflewering van die HTS wat aan prof CH Rautenbach opgedra word, ook 'n bydrae oor die Kerk se sendingwerk verskyn. Prof Rautenbach is vandag die enigste oorlewende lid van die Nederduitsch Hervormde Sendinggenootskap; die liggaam wat in die vroeë dertigerjare van hierdie eeu die gehoorsaamheid aan die opdrag van die Heer probeer nakom het op 'n tydstip toe die Kerk self koud en afsydig van dié opdrag gestaan het. In 1945 het prof Rautenbach ook met sy bekende skerp en deurdagte argumentasie ' $n$ bydrae gelewer tot die besluit van die Kerk om voortaan self die sendingtaak ter hand te neem (Nederduitsch Hervormde Kerk van Afrika 1945).

\section{Samevatting}

Sending en Sendingwetenskap, ook binne die Nederduitsch Hervormde Kerk, gaan tans deur 'n tyd van krisis en toetsing. In hierdie 
artikel sal steeds gehou word aan die oortuiging dat die Kerk se sendingtaak in die wêreld nie voltooi en verby is nie, maar dat ons heel aan die begin staan van 'n opwindende en uitdagende nuwe tydperk.

\section{SENDINGWETENSKAP VANDAG}

Dit is algemene kennis dat die Sendingwetenskap 'n baie jong teologiese vak is. In die Nederduitsch Hervormde Kerk is dit nog meer so. Dit wil voorkom of dit eers sedert ongeveer 1955 was (dus enkele jare nadat die Kerk met sendingwerk begin het) dat wyle prof HP Wolmarans lesings in Sendingwetenskap in die Fakulteit Teologie (Afd A) aan die Universiteit van Pretoria begin aanbied het. Dié doseerwerk is voortgesit en op hegter grondslag geplaas deur prof FJ van Zyl wat gedurende die jare 1960 tot 1978 die leerstoel in Godsdiens- en Sendingwetenskap beklee het. Prof Van Zyl is in 1979 opgevolg deur prof PJ van der Merwe. Dit bly bevrugtend om na stemme uit die verlede te luister. Daarom is dit nodig om die geskiedenis van ons eie sendingwerk en die beoefening van die Sendingwetenskap binne die Nederduitsch Hervormde Kerk te begin opteken. Die kerk van Christus was van die eerste eeu van sy bestaan af reeds besig om die evangelie aan die heidene te verkondig. Uit diê vroeë tyd van die Christelike kerk se geskiedenis vind ons egter nie 'n behoefte of pogings om die sendingopdrag en sendingprobleme op 'n sistematies-wetenskaplike wyse te deurdink nie.

Eerste tekens van werk van 'n sendingwetenskaplike aard word teruggevoer na die 13de eeu in die werk van Ramon Lull. JH Bavinck (1954: 7) sê dat dit Thomas Aquinas was wat in sy Summa contra gentiles die eerste sistematiese verhandeling van die sending gegee het. Ook Gÿsbertus Voetius het moeite gedoen om die beginsels vir die sendingwerk uit die Skrif af te lei. Verdere grondliggende bydraes in die totstandkoming van die Sendingwetenskap is deur Piëtiste soos Von Zinzendorf, Francke en William Carey gelewer. Dit moet vir die kerk beskamend bly dat dit die Piëtisme was, 'n beweging teen wie daar so dikwels striemende kritiek vanuit die kerk gekom het, wat gedurende lang periodes van slaap en ongehoorsaamheid binne die offisiële kerk, die enigste was om die ywer vir en gehoorsaamheid aan die opdrag van die Heer lewend te hou. Om sendingbelangstelling lewend te hou, is volledige berigte opgestel oor wat op die verre sendingterreine gebeur. So is omvangryke sendingliteratuur geskep (Van Zyl 1960-1978: 1). Alle navorsers stem saam dat dit eintlik maar eers die $19 \mathrm{de}$ eeu was wat 
werklik as die geboorte-uur van die Sendingwetenskap aangedui kan word. In 1867 is Alexander Duff in Edinburgh as professor in Sendingwetenskap aangestel, en begin Carl Plath in Duitsland en Rufus Anderson in Amerika met lesings. Ook Friedrich Schleiermacher het in sy werk verskillende sendingvrae aangeroer. Hy was ook die eerste teoloog wat aan die begin van die 19 de eeu aandag skenk aan die ensiklopediese plek van die Sendingwetenskap in die teologie (Verkuyl 1975: 21). Die Evangelische Missionslehre van Gustav Warneck word algemeen beskou as die eerste volwaardige werk van sendingwetenskaplike aard. Martin Kähler in die 19de eeu en Karl Barth, asook Hendrik Kraemer in die 20ste eeu, het deurslaggewend opgetree om die sending as onontbeerlike wesensaspek van die kerk se werk erken te kry.

Die 20ste eeu het 'n besondere worsteling met en nadruk op die kerk se sendingwerk en die Sendingwetenskap gebring. Albei wêreldoorloë het diepgrypende herbesinning en herformulerings onafwendbaar gemaak. Die bespreking en optekening van sendingprobleme tydens die hele reeks sendingkonferensies sedert 1910 was van groot betekenis vir die uitbouing van die Sendingwetenskap.

Terwyl die eerste 75 jaar van hierdie eeu as 'n hoogtepunt geld in die aktiwiteite op sendingwetenskaplike terrein, is dié belangstelling, soos reeds aangetoon, veral in Europa tans sterk aan die kwyn. In die kringe van die Church Growth School van Donald McGavran in die VSA word die Sendingwetenskap steeds aktief bedryf. In Europa gaan die sending, as gevolg van allerlei politieke ontwikkelinge en ook onder invloed van die ekumene al meer op in sosiale betrokkenheid, die teologie van die rewolusie of die teologie van die bevryding. Dit lei tot tanende belangstelling in die Sendingwetenskap.

In die verlede is sowel die belangrikheid as die selfstandigheid van die Sendingwetenskap in die teologiese ensiklopedie misken. A Kuyper en JH Bavinck het, soos Schleiermacher, die Sendingwetenskap by die diakonologiese vakke gegroepeer. Gustav Warneck wou die Sendingwetenskap in drie deel en dit plaas by die Bybelwetenskappe, Kerkgeskiedenis en Praktiese Teologie. Veral in die Engelse teologie is die weg gevolg waar Sendingwetenskap nie as selfstandige vak behandel is nie, maar waar daar van elke dosent verwag is om aan die missionêre aspek van sy vak aandag te gee. Dit was hoofsaaklik in Duitsland waar Sendingwetenskap, net soos in Suid-Afrika, saam met Godsdienswetenskap as 'n selfstandige sesde vak binne die teologiese ensiklopedie aangebied is. 
Binne die Nederduitsch Hervormde Kerk is steeds gekies vir die benaming Sendingwetenskap bo ander benaminge. Wolmarans (1956: 19) het die vak onderverdeel in Sendingleer, Sendingmetode en Sendinggeskiedenis. Die sendingtaak, glo hy, is 'n taak van die kerk en daarom is kennis van die verkieslikste sendingmetodes ook ' $n$ vereiste vir diegene wat as ampsdraers in die kerk opgelei word. Dit kan nie maar aan die sendingopleiding oorgelaat word nie. Hoewel daar raakpunte is met verskeie ander teologiese dissiplines, kies hy vir Sendingwetenskap met hierdie driedeling as 'n selfstandige vak saam met Godsdienswetenskap.

Op hierdie spoor het sowel FJ van $\mathrm{Zyl}$ as PJ van der Merwe voortgegaan. Van Zyl gee voorkeur aan 'n tweeledige indeling van die vak, naamlik Sendingteorie en Sendinggeskiedenis (Van Zyl 19601978: 3). Van der Merwe gee voorkeur aan die benaming Sendingwetenskap bo Missiologie en kies vir dié vak met 'n eie leerstoel waar 'n dialogiese verband met ander departemente, veral Praktiese Teologie en Godsdienswetenskap gehandhaaf word. Hy wil sowel die selfstandigheid as die geskakeldheid van Sendingwetenskap met ander teologiese vakke verreken hê (Van der Merwe $s$ a a: 3.4).

Die volgende drieledige indeling van die Sendingwetenskap blyk steeds die mees doeltreffende te wees.

\section{- Sendingteorie}

Hier word eerstens inleidingskwessies behandel oor die naam, geskiedenis, ensiklopediese plek en taak van die Sendingwetenskap; vervolgens die fundering van die sending; doel en motiewe; inhoud en benadering; sendingmetodiek en sendingbeleid.

\section{- Sendinggeskiedenis}

Die Sendinggeskiedenis moet, ondanks hoeveel raakpunte met die Kerkgeskiedenis, as selfstandige onderdeel van Sendingwetenskap behandel word, anders kom dit nie tot sy reg nie. Die taak van die Sendinggeskiedenis is om na te gaan wat die kerk in die verlede ten opsigte van die sendingopdrag van die Heer gedoen het. Dit moet beskryf word en uit dié beskrywing moet ontledend aangetoon word hoe die kerk sy sendingopdrag uitgevoer het. Het die kerk hom gehou aan die norme wat die Sendingteorie vir hom uit die Skrif afgelei en aangetoon het? Watter sendingbenaderings en -metodes het geslaag en watter nie? Die Sendinggeskiedenis moet vir die kerk 'n spieël voorhou waarin hy homself in sy gehoorsaamheid of ongehoorsaamheid voor God kan sien. 


\section{- Sendingteologie}

Die taak van die Sendingteologie is om die inhoude wat die Sendingteorie en Sendinggeskiedenis daargestel het, teologies te deurdink en die resultaat van dié arbeid vir die kerk beskikbaar te stel. Uit ' $n$ wye verskeidenheid temas wat hier aangesny moet word, word net die volgende aangestip: Die teologie van die Godsdienste en ideologieë; kommunikasie met die sendingobjek; kerk en samelewing; kerk en kultuur; sending en evangelisasie.

Oor laasgenoemde, naamlik sending en evangelisasie, volg hier enkele opmerkings. Dit is ' $n$ voldonge feit dat bykans al die prinsipiële onderskeidings tussen sending en evangelisasie uit die verlede vandag vervaag of heeltemal weggeval het. Om in die werk van die kerk volledige skeiding tussen sending en evangelisasie te handhaaf, word al meer kunsmatig. Die enigste werklike onderskeid wat tans nog bestaan, in die Nederduitsch Hervormde Kerk in elk geval, is dat sending beskou word as die verkondiging van die evangelie aan mense van alle ander rasse en evangelisasie as die werk en verkondiging van die kerk aan ons eie volksgenote en ander blanke Europeërs. Sou dit nie beter en meer logies wees om voortaan te praat oor sending onder blankes en sending onder ander volke nie? Is die werk waarmee die kerk tans onder die benaming evangelisasie besig is, werklik in enige opsig iets wesenlik anders as normale sendingwerk? Differensiasie ten opsigte van kultuur en werkkragte is noodsaaklik, maar om dié twee sake té skerp te skei, lyk onnodig. Dit gaan ook in die werk onder die blankes al minder om kerkvervreemdes en al meer om heidene, mense wat nie meer kinders van verlore seuns is nie, maar kleinkinders en agterkleinkinders.

Rondom hierdie suggesties skuil baie voetangels. Maar dit moet 'n keer teologies behoorlik deurdink word. ' $n$ Prinsipiële skeiding tussen sending en evangelisasie lyk in elk geval nie meer sinvol nie, hoogstens slegs prakties.

Vroeër is reeds gestel dat die selfstandigheid, belangrikheid en omvang van die Sendingwetenskap dikwels misken word. Daar is natuurlik ook ' $n$ ander gevaar. Dit is dat die vak se omvang en belangrikheid totaal oorskat word. Dit lei tot opheffing van die Sendingwetenskap. As alles Sendingwetenskap is, is daar van die vak later niks meer oor nie. Is dit nie juis die lot wat die sending en die Sendingwetenskap in die ekumeniese teologie getref het nie? Die sending is geleidelik opgelos in betrokkenheid van die kerk by same- 
lewingstrukture. Hoe meer dit gebeur het, hoe luider is geëis dat al die werk van die kerk eintlik maar sendingwerk is. Die gevolg is dat daar in die huidige ekumeniese teologie eintlik niks meer van die Bybelse visie op sending as wesensaspek van die kerk se lewe en werk oorgebly het nie.

Dié gevaar bestaan ook by teoloë van die Afrikaanse kerke. Hier word verwys na onlangse publikasies van twee teoloë uit die geledere van die Nederduitse Gereformeerde Kerk, naamlik DJ Bosch en CM Pauw. Hoewel albei laat blyk dat hulle bewus is van die gevaar van panmissionisme en ook daarteen waarsku, verval albei tog daarin. Bosch (1986) sien uitsluitlike klem op bekering en kerkplanting as 'n ongeregverdigde reduksie van sending en 'n verskraling van wat die Bybelse woord sōzein beteken. Sending is bekering en kerkplanting ook, maar dit is baie meer as net dit. Om by geregtigheid, ontwikkeling, reformasie en vrede betrokke te raak, behoort ook intrinsiek tot die Christelike geloof en sending. Betrokkenheid by aangeleenthede van vrede en geregtigheid beteken nie 'n wegbeweeg van die sentrum van die kerk se sending nie, maar juis ' $n$ al duideliker beweging na die sentrum toe.

Sending beteken dat mense geroep word tot 'n betrokkenheid in die strukture van die samelewing waarin hulle woon en ook elders in die wêreld; dit beteken betrokkenheid in aangeleenthede van geregtigheid, vrede, ontwikkeling en liefdadigheid, in dinge wat die gesin, die gemeenskap, die nasie en die wểreld raak (Bosch 1986: 9).

Pauw (1986: 78) sê die feit dat teologie in sy wese missionêr gerig moet wees en as 't ware dialoog met die wêreld moet word, plaas Sendingwetenskap in die rol van wegwyser en inisieerder. Die ander vakke moet as 't ware van hulle 'bysiendheid' genees word. Die aandag van die Sendingwetenskap word volgens hom ook gevra vir die bestaansnood van mense: individue, groepe en volkere. Dit laat die aksent val op wêrelddiakonaat asook ontwikkeling-samewerking. Uiteindelik bring dit ook die vraag na die sosio-politieke konsekwensies van die evangelie na vore.

Dié sienings van Bosch en Pauw oor die taak en inhoud van sending en Sendingwetenskap verskil nie meer beduidend van dié van die Wêreldraad van Kerke nie. Behalwe dat dit die klem te sterk verlê na sosiale betrokkenheid, het dit die neiging om al die werk van die kerk as sendingwerk te sien. Verder klink dit ietwat na 'n oorskatting van die 
terrein van die Sendingwetenskap en sal ander vakwetenskaplikes in die teologie iets van 'n verwaandheid by die Sendingwetenskaplike laat vermoed.

\section{Samevatting}

Die plek, belangrikheid en selfstandigheid van die Sendingwetenskap moet nòg geringgeskat nòg oorskat word. Ons wil hier liewer min of meer aansluit by die meer beskeie definisie van FJ van Zyl ten opsigte van die taak, opdrag en inhoud van die Sendingwetenskap:

Die Sendingwetenskap is dié vak waarin die kerk funderend, krities en korrigerend ondersoek instel oor die vraag of sy woord en daad ooreenstem met die getuienis van die Heilige Skrif met betrekking tot sy besondere handeling in en aan die wểreld wat van God vervreemd is en wat as sending aangedui word (Van Zyl 1960-1978: 1).

Ook die definisie waaronder Sendingwetenskap huidiglik in die Departement Godsdiens- en Sendingwetenskap (Afd A) aan die Universiteit van Pretoria doseer word, is meer beskeie ten opsigte van die vak se opdrag en omvang. Maar dit laat geskied ons insiens meer reg aan die Bybelse en teologiese fundering en orde oor wat sending wesenlik is. Dit kan die sending vrywaar van 'n situasie waar alles sending gemaak word en van die sending later niks meer oor is nie. Van der Merwe (s a b: 1.2) stel dit so:

Sending is die kerklike en menslike deelname aan God se bekendmaking van sy liefde en genade-aanbod deur sy Seun aan die mensdom wat deur hulle sonde in uitsiglose ellende versink het, sodat hulle hul kan bekeer, deel kan word van sy koninkryk en God in dankbaarheid kan verheerlik. Sendingwetenskap is die vak wat wetenskaplike ondersoek en besinning oor die sending doen.

Hierdie definisie mag as 'n verskraling of redusering afgemaak word; ons is oortuig dat dit na aan die Bybelse inhoud van wat sending is, bly.

\section{DIE HUIDIGE TONEEL}

Hoewel hier primêr gehandel word oor die sendingteorie en -praktyk binne die Nederduitsch Hervormde Kerk, kan dit nie losgemaak word 
van wat teologies in die wêreld oor die sending gedink en gepraat word nie. Daarom word hier enkele opmerkings gemaak oor die huidige sendingsituasie in die wêreld.

Die pad vanaf die eerste internasionale sendingkonferensie wat in 1910 in Edinburgh gehou is tot by die laaste algemene vergadering van die Wêreldraad van Kerke in Vancouver in 1983 was 'n lang pad, nie net wat tydspan betref nie, maar ook wat betref die omvang van ontwikkeling in die kerk se sendingdenke.

Die ontwikkeling binne die sendingteologie wat die laaste jare rewolusionêre afmetings aangeneem het, is sterk voortgestu deur twee wêreldoorloë met hulle diepgrypende naweë van skok, skuld, ontreddering en pogings om verdere katastrofes van dié aard te help voorkom. Elke keer is daar ' $n$ beskuldigende vinger na die kerk gewys.

'n Beweging wat op die ekumene en die sendingteologiese ontwikkelinge in die 20ste eeu sterk invloed uitgeoefen het, is die Piëtisme. Dié invloed is nog nooit ten volle gepeil en beskryf nie. In die laat 19de eeu was daar in Europa en Amerika 'n sterk oplewing van die Piëtisme. Behalwe die klem op die indiwidu en sy bekering het die Piëtisme altyd ook klem gelê op die warmte en innigheid van die geloofsbelewing. Dit het gelei tot die drang om 'n keer op wêreldwye skaal met Christene saam te wees. Al het die aandag vir die indiwidu se bekering in die latere ekumeniese sendingteologie getaan, het ander sterk Piëtistiese ondertone sy greep op die ekumene behou. Die soms dweperige en eensydige klem op die mens en sy bekering het verskuif na die mens en sy nood, sy armoede en verdrukking. Die gevoelvolle ervaring van saamwees is soms so oorweldigend en verdowend dat dit die vraag na onderskeiding en waarheid oorwoeker. Uit rapporte oor Bybelstudie en kleingroepbesprekings klink telkens 'n egte piëtistiese gees op.

Ook politieke ontwikkelinge gedurende die 20 ste eeu het die sendingteologie sterk beïnvloed. Die onafhanklikwording van talle Derde Wêreld-lande het gaandeweg ook by die kerk in dié lande antipatie en selfs vyandigheid teen die kerk en die Weste tot gevolg gehad. Toonaangewende teoloë uit Wes-Europa vanwaar die 19de-eeuse kolonialisme gevoer is, was nie in staat om die stuk verlede wat as skuld ervaar is, gelowig, teologies en gebalanseerd te verwerk nie. In plaas daarvan is by die kerk 'n onbybelse skuldbewussyn gekweek. In 'n angsvallige poging om iets van dié skuld uit die verlede te delg, is die klem totaal verskuif na die mens en sy ellende, terwyl die blik op God en sy Ryk verdof het.

Waar al die klem in 1910 op die sending geval het, het dit gaandeweg 
ná die Eerste Wêreldoorlog verskuif na die vraag oor die wese van die kerk. Dit was terselfdertyd 'n verskuiwing van die 'hoe' na die 'wat' van sending. Terwyl die rewolusionêre tendense in die sendingteologie na 1960 aan die lig begin tree het en na 1973 tot volle ontwikkeling gekom het, moet die meer direkte oorsprong daarvan teruggevoer word na die denke en bespreking rondom die Missio Dei-begrip tydens die Willingenkonferensie in 1952.

Sedert die stigting van die Wêreldraad van Kerke in 1948 het daar aandrang begin kom vir 'n herformulering van die sendingteologie. Die ou begrip Missio Dei is na vore gehaal om aan die sending 'n nuwe Bybelse basis te probeer gee. Die inisiatief tot sending is die Drie-Enige God self.

Om sending as God se werk te sien, is op sigself 'n winspunt. Mettertyd is daar egter allerlei radikale nuanses aan dié begrip geheg.

In the years that followed, Missio Dei became a neologism that blurred God's providential governance over the nations with the church's mission. Radical formulations came to the fore until Missio Dei was so reinterpreted and modified that it came to mean the action of God in carrying out His judgements and His ameliorating work among the nations in the revolutionary movements of our day (Glasser 1983: 92).

Humanisering word die doel van sending. Die kerk se verkondiging hoef nie meer ingelui te word met 'n oproep tot bekering nie. Daar is geen wesenlike verskil tussen Christene en nie-Christene nie. Die werk van God word gevind in al die bewegings wat hulle beywer vir die humanisering van indiwidue en die gemeenskap.

God se sending en wat God besig is om in die wêreld te doen, is na Willingen as sinonieme aanvaar. Die kerk het nie 'n sending van sy eie nie. Die kerk moet deelneem aan God se sending, aan wat God besig is om in die geskiedenis te doen.

When the conviction began to grow, however, that mission must increasingly be interpreted in terms of 'what God is doing in the world', in accordance with the secularized understanding of Missio $D e i$, a momentum for change began to express itself in a series of strikingly new movements (Glasser 1983: 94).

$\mathrm{Na} 1961$ het die sendingteologie in twee rigtings begin ontwikkel. Die ekumeniese sendingteologie is ontwikkel binne die Kommissie vir Wêreldsending en -evangelisasie, met sterk klem op betrokkenheid by 
onderdrukkende strukture in die samelewing. In protes teen die nuwe inhoude wat deur die ekumene aan die sending gegee is, het ' $n$ evangeliese sendingteologie ontwikkel wat mettertyd bekend geraak het as die Lausanne-beweging (Van Wyk 1986). Dit is moeilik om diê twee sendingmodelle altyd duidelik van mekaar te onderskei. Vanweë oorvleueling en uitsprake wat dikwels botsend is, is oorsigtelikheid haas onmoontlik. Die indruk bestaan dat die kloof tussen die twee rigtings besig is om te vernou, veral omdat baie evangelicals sterker betrokkenheid van die kerk by ' $n$ verhumanisering van die samelewing toegee.

Om uitdrukking te gee aan die huidige verstaan van die sending word deur die ekumene gebruik gemaak van die begrip Christelike presensie. Die kerk moet maar net in die naam van Christus, in die wêreld teenwoordig wees, anoniem, luisterend, gereed om betrokke te raak by elke stryd teen dehumanisering en demoniese magte.

Soos reeds aangestip, is die sendingwerk van die kerk asook die Sendingwetenskap in die laat sestiger- en begin sewentigerjare opgelos in die teologie van die rewolusie en die teologie van die bevryding. Die ekumene se besondere waardering van die nie-Christelike godsdienste het mettertyd gelei tot 'n verdere dwaling, naamlik dié van die universalisme. Daar is geen wesenlike verskil tussen Christene en nie-Christene nie. Alle godsdienste is die vrug van openbaring. Elke mens kan behou word, solank hy die openbaring waarop sy godsdiens berus, ernstig neem.

Waar dít geglo word, het die prediking oor die gerig van God natuurlik oorbodig en onmoontlik geword; ook enige vermelding oor die hel of die ewige verdoemenis. Dit is begryplik dat hier ook nie meer van sending sprake kan wees nie. Dit is vir die kerk voldoende uitvoering van sy sendingopdrag om met politieke en sosiale aksies die menslike samelewing te vervolmaak.

\section{Samevatting}

Wie deesdae nie saam swem in die stroom van die ekumeniese sendingteologie nie, word as irrelevant afgeskryf. Dié sendingteologie kon 'n suiwerende en heilsame invloed op die eensydighede van vroeëre sendingteologieë uitoefen deurdat dit byvoorbeeld groter aandag en bewoënheid met die sendingobjek openbaar. Ongelukkig het dit self in soveel eensydighede verval dat enige moontlike winspunte totaal verydel is. Tans kan die kerk en die teologie beswaarlik ontkom 
aan die dwingende vraag of ons in die huidige sendingteologie nog met die evangelie van Jesus Christus te doen het en of dit reeds verruil is vir 'n ander evangelie (Gal 1: 6-9). Immers, in die neiging tot universalisme wat by soveel vooraanstaande teoloë na vore tree, word die versoening van God en mens deur Jesus Christus radikaal aangetas.

\section{DIE NEDERDUITSCH HERVORMDE KERK EN DIE SENDING}

Die aandag is reeds gevestig op enkele rigtinggewende uitsprake wat van drie Hervormde akademici op die terrein van die sending en die Sendingwetenskap gekom het. Om enigsins 'n oorsig te kry van wat gedurende die afgelope 50 jaar binne die Nederduitsch Hervormde Kerk oor die sending gedink en geskryf is, moet daar ook gelet word op wat ander sendingwetenskaplikes en teoloë met verloop van tyd ten opsigte van die kerk in die algemeen se sendingtaak uitgespreek het; verder moet geluister word na uitsprake van die Kerk self en ook wat die Kerk in sy Wet en Bepalings sê.

\subsection{Die fundering van die sending}

Wat het binne die Nederduitsch Hervormde Kerk gebeur terwyl daar in die kerk in die wêreld ' $n$ diepgaande gesprek oor die kerk en sy taak aan die gang was? Hoe het die Hervormde Kerk die fundering van sy sendingopdrag in die Skrif verstaan? Die afgelope jare word in byna elke sendingwetenskaplike werk beklemtoon dat die kerk in hierdie tyd van krisis en toetsing nie meer sy sendingopdrag biblisisties net op enkele Bybeltekste kan fundeer nie. Daar word in die Bybel 'n breë wesenlike missionêre dimensie ontdek (Bosch 1979: 51). Dit moet die basis van die sendingopdrag aan die kerk wees.

In sy doktorale proefskrif het HG van der Westhuizen (1969) die aanvanklike houding in die Nederduitsch Hervormde Kerk teenoor sending gedurende die tydperk 1853-1928 geskets. Daaruit blyk dat Hervormde teoloë reeds op dié stadium die sendingopdrag aan die kerk vanuit 'n baie breë Bybelse perspektief gefundeer het.

Die sendingbevel van Christus in Matteus 28 het altyd 'n groot rol gespeel in die fundering van die sending. Daar was egter aanvoeling dat dié opdrag aanvaar moet word as die samevatting van 'n diepliggende missionêre dimensie in die Skrif. Na die Algemene Kerkvergadering van 1945 skryf Joh Dreyer in 'n memorandum: Die taak om die evangelie tot aan die einde van die aarde te verkondig, mag nie die 
stiefkind van die Kerk wees nie, maar dit is sy eintlike taak en sy eerste plig (Van Wyk 1986: 612).

Wolmarans (1955-1958: 3) stel dat deur die hele Ou Testament blyk dat Israel bewus was van 'n roeping wat hy teenoor die hele wêreld te vervul gehad het. Die belofte aan Abraham het gesorg dat die geestelike leiers van Israel, soos die profete, die roeping van Israel as die draer van die Godsopenbaring na die hele wêreld, nooit kon vergeet nie. Van hierdie Israel is die Nuwe-Testamentiese gemeente die opvolger en voortsetter, die geestelike Israel wat erfgenaam is van die belofte aan Abraham. Jesus self het die evangelie aan die Samaritaanse vrou en ander heidene verkondig. Uit sy onderrig aan die dissipels dat hulle die sout van die aarde is, blyk dat hulle alles wat hulle gehoor en van Hom ontvang het, aan ander moes gaan meedeel. Dit was vir die dissipels van Jesus vanselfsprekend om die boodskap van die Christus van God aan die wêreld te bring, afgesien selfs van die bevel in Matteus 28. ' $M$ a $w$ die sendingbevel vind noue aansluiting by die hele onderrig aan sy dissipels' (Wolmarans 1955-58: 4). Die sendingopdrag was vir die dissipels so 'n vanselfsprekende saak dat al sou die Heer die uitdruklike sendingbevel in Matteus 28: 19 nie gegee het nie, die sendingaksie nogtans sou gevolg het. Wolmarans (1955-1958: 27) beklemtoon verder die pneumatologiese en eskatologiese dimensies van die sending.

Ook FJ van Zyl wil die sendingopdrag aan die kerk baie breed en omvattend in die Skrif fundeer. Hy vind daarvoor aansluiting by die apostolaatsgedagte van Van Ruler, Kraemer en Hoekendyk (Van Zyl 1960-1978: 1). Die apostolaatsgedagte verstaan hy as ' $n$ reaksie teen die introversie van die kerk. 'n Introverte kerk is ' $n$ kerk wat net op homself gerig is, wat net aan sy eie bestaan en voortbestaan dink. Die missionêre moment, en wel in die gestalte van die verkondiging van die evangelie, vorm 'n wesenlike moment in die Nuwe-Testamentiese apostolaat. Die teenwoordigheid van die Heilige Gees is onontbeerlik vir die apostolaat. In die sending is die kerk werklik kerk en as hy hierdie roeping verwaarloos, is hy 'n ongehoorsame kerk.

PS Dreyer (1964: 183) fundeer die sending nie net in Matteus 28: 19 nie, maar baie breed ook in die Ou Testament, byvoorbeeld Psalm 24: 1 en 2. Hiervandaan trek hy 'n lyn deur na Filippense 2: 11 en 12.

Van der Merwe ( $\mathrm{a}$ b: $1-3$ ) wys daarop dat God se bemoeienis met die mense van die begin af ' $n$ universele karakter dra. Dit gaan nie net om Abraham en die verbondsvolk nie, maar juis in hulle verkiesing om die wêreld.

Terwyl die Bybel en veral die Nuwe Testament 'n missionêre onder- 
toon het, het die kerk soos dit in die Nuwe Testament na vore kom, 'n missionêre inslag. Die vernaamste taak van die kerk is om die koninkryk van God in die wêreld te proklameer en in dié proses al wyer in die wêreld uit te kring.

\subsection{Die doel van die sending}

Anders as in die piëtisties-georiënteerde fundering en benadering tot die sending, het die bekering van mense of die redding van siele in die individualistiese sin van die woord nooit in die Nederduitsch Hervormde Kerk 'n prominente rol gespeel nie. As vernaamste oorkoepelende oogmerk met sendingwerk het gegeld die eer van God en die verbreiding van sy koninkryk (Van der Westhuizen 1969: 293-294). Dié doel van die Hervormde Kerk met sy sendingwerk is bykans deur elke pleitbesorger vir sending uitgespreek. Daarnaas het, as 'n meer direkte oogmerk, die totstandkoming (planting) van 'n eie selfstandige kerk of kerke gegeld. Dit was van die begin af die groot ideaal. In die Akte van Oprigting van die Nederduitsch Hervormde Sendinggenootskap in 1929 word die 'vestiging en organisasie van naturelle gemeentes tot 'n selfstandige kerk' as een van die eerste oogmerke aangestip (Van Wyk 1986: 604).

Vanaf 1951 het die Kerk dit in Artikel III van sy Kerkwet as uitdruklike doel met sy sendingwerk uitgespreek: die stigting van volkskerke onder die verskillende volksgroepe. Van Zyl (1954: 159) stel dit so: 'Ons stel ons ten doel om 'n eie Bantoekerk so gou moontlik te laat ontwikkel, wat geheel onafhanklik en selfonderhoudend sal wees.' Ook Van der Merwe ( $\mathrm{a}$ b: 30 ) sien kerkplanting as 'n vername oogmerk van sending.

\subsection{Motiewe van sending}

'Sending is ' $n$ deel van die vervulling van die apostoliese opdrag van die Kerk. Dit geskied op grond van en in gehoorsaamheid aan Gods Woord. Teologiese besinning is daarom die eerste en grondliggende vereiste by die ontwerp van 'n sendingbeleid' (Dreyer 1959: 164). Hierdie woorde van PS Dreyer is 'n samevatting van 'n refrein wat aanhoudend in die Hervormde Kerk voortgedra is. Dit is die kerk se roeping om die evangelie aan die heidene te verkondig. As die Nederduitsch Hervormde Kerk kerk van Christus wil bly, moet hy aan dié roeping gehoorsaam wees. Word hy aan dié roeping ontrou en ongehoorsaam, verbeur hy sy voorreg om kerk van Christus te wees.

Die gehoorsaamheidsmotief kan geld as die belangrikste en bykans 
enigste sendingmotief binne die Nederduitsch Hervormde Kerk. In talle sendingwetenskaplike werke kom daar ontledings voor van die sendingmotiewe, suiwer en onsuiwer, wat veral in die 19de eeu gegeld het. As daar in die Nederduitsch Hervormde Kerk en sy teologie van 'n ander sendingmotief naas die gehoorsaamheidsmotief sprake moet wees, dan is dit dat daar soms gesê is dat sending gedoen moet word ter wille van die veilige toekoms van land en volk en die suksesvolle afweer van die Marxistiese bedreiging. Ons het as kerk in die eerste plek die opdrag tot sending van God self. Tweedens word die taak ons opgelê deur ons verantwoordelikheid teenoor die land en volk waarvan ons ' $n$ deel is (Dreyer 1961: 181). As ons aan die opdrag van God ongehoorsaam is, kan God dalk die roede van die Kommunisme gebruik om ons tot inkeer te bring (Dreyer 1951: 150). Soms het dit ook voorgekom dat, naas die roeping van die kerk, die roeping van die Afrikanervolk aan die Suidpunt van Afrika aanvaar is as motief om sendingwerk te doen (Dreyer 1951: 14).

Of hierdie motiewe, wat duidelik sekondêr ten opsigte van die wesenlike motief, naamlik gehoorsaamheid, gestel word, noodwendig as onsuiwer veroordeel moet word, is ' $n$ verdere vraag wat nie binne die bestek van hierdie artikel beredeneer kan word nie.

\subsection{Die kerk en sosiaal-maatskaplike strukture}

Die kerk se betrokkenheid in die stryd teen onderdrukkende maatskaplike, ekonomiese en politieke strukture staan tans in die brandpunt van die Sendingteologie. Baie glo dat hierdie betrokkenheid verder moet uitkring. Ander is bevrees dat die klem op hierdie betrokkenheid reeds die Bybelse visie op die sending onherstelbaar geskend het.

Wat word binne die Nederduitsch Hervormde Kerk hieroor gesê? Het die klem op die gehoorsaamheidsmotief en sending as verkondiging die kerk ongevoelig gemaak vir die liggaamlike nood van die mens? Wolmarans (1955-1958: 59) leer soos volg: Veral aan diegene wat Jesus Christus bely as Verlosser, word die eis van naasteliefde gestel. Die gebrek aan naasteliefde en sosiale geregtigheid kan die kerstening van die heidense volke geweldig in die weg staan en het dit al op meer as een sendingterrein gedoen.

Die kerk self het aanhoudend enige vorm van diskriminasie, of krenkende, beledigende en vernederende reëlings of optredes tussen mense, op welke terrein ook al, as onversoenbaar met die Christelike verantwoordelikheidsin verwerp (Algemene Kerkvergadering: 1976). 
Terselfdertyd het die Hervormde Kerk bly glo en bely dat verkondiging sy primêre sendingtaak is, en nie die betrokkenheid by 'n stryd op sosiale vlak nie.

The nature of the Church of Christ is such that the Word it proclaims in the world, has in itself the power to 'pluck up and break down, to destroy and to overthrow, to build and to plant' (Jer 1: 10). It is not the function of the Church in itself therefore to create new relations between people. This is the function of the Word to which the bearer himself is subjected (Kommissie van die Algemene Kerkvergadering 1960).

Die evangelie het in homself die krag om, waar dit ingaan in die lewe van 'n gemeenskap, mettertyd die strukture van dié samelewing te kersten en te omvorm.

\subsection{Evangelie en kultuur}

Die kerk het dit uit die staanspoor van baie groot belang beskou dat die evangelie inheems moet word onder die volke aan wie Christus verkondig word. Daar moes in die sendingwerk gepoog word om swartmense binne hulle stamverband te hou en hulle nie kultureel te ontwortel nie. Daarom moes dit nie blankes wees nie, maar swartes wat self die Woord aan hulle eie mense verkondig. Kultuurvorme soos die lobolostelsel moet eerbiedig word. Daar is geglo dat die evangelie self die heidense invloede sou kersten.

Wolmarans (1955-1958: 42) stel dat omdat die evangelie van Christus nie van hierdie wêreld is nie, spreek dit tot alle mense van alle kulture en geen verandering in kultuur is noodsaaklik vir die aanvaarding van die evangelie nie. Dit sal dwaas wees om verandering in kulturele en sedelike opsig as voorwaarde te stel vir die verkondiging en aanvaarding van die boodskap van verlossing. Wat wel moet en sal gebeur, is dat die evangelie reformerend inwerk op die kulturele en sedelike lewe van die bekeerling. Daarvoor is nodig dat die evangelie gebring sal word deur middel van die taal en in die kultuuridioom van die sendingobjek. Die evangelie dra in homself die krag om kultuurgrense oor te steek, sonder dat dit nodig is dat die kultuur van ò die sendingsubjek ò die sendingobjek in die proses vernietig word.

\subsection{Sendingpraktyk binne die Nederduitsch Hervormde Kerk}

Met wat voorafgegaan het, is verskillende aspekte van die Hervormde Kerk se sendingbenadering en sendingbeleid reeds geskets. Benewens 
die reeds gemelde doktorale proefskrif van HG van der Westhuizen, is die formulering en die aanvanklike uitvoering van die Nederduitsch Hervormde Kerk se sendingbeleid gedurende die tydperk 1928-1977 asook die huidige stand van sake in die Hervormde Kerk in Suidelike Afrika in drie onlangse studies kortweg aangedui (Van Wyk 1986: 600-623; Botha 1987: 20-26; Van Tonder 1987: 35-47). Die Hervormde Kerk in Suidelike Afrika het in 1977 as 'n selfstandige kerk tot stand gekom.

Die jaar 1951 was 'n belangrike mylpaal in die Hervormde Kerk se sendingwerk. Daar is nie alleen die latere omstrede motivering tot Artikel III in die Kerkwet opgeneem nie, maar ook 'n hele reeks bepalings ten opsigte van die apostolaat van die Kerk wat mettertyd duidelike rigting aan die Kerk se sendingwerk sou gee (vgl Van Wyk 1986: 615).

Die Kerk het in sy teologiese denke oor hierdie saak steeds vasgehou aan die Bybelse gedagte van 'n volkereverskeidenheid waarvan die voortbestaan nie as imperatief aan die Kerk opgedra is nie, maar dan tog as 'n gegewenheid waarmee die Kerk in sy lewe en werk rekening mag hou en wat nie op sigself sondig is nie.

Van Zyl (1954: 159) omskryf die sendingbeleid van die Kerk soos volg:

(i) Die Kerk gaan van die standpunt uit dat die evangelie deur die Nie-Blanke aan die Nie-Blanke gebring moet word. Daarom is ons nie ten gunste van blanke sendelinge in nie-blanke gebiede nie.

(ii) Ons wil 'n sendingbeleid daarstel wat ooreenstem met die gees en beginsels van ons Kerk, en daarom is dit noodsaaklik dat daar 'n opleiding van nie-blanke leraars sal wees onder toesig van ons Kerk.

(iii) Ons stel ons ten doel om 'n eie Bantoekerk so gou moontlik te laat ontwikkel, wat geheel onafhanklik en selfonderhoudend sal wees.

(iv) Wat onderwys betref, was dit nog altyd ons standpunt dat dit die verantwoordelikheid van die staat en nie van die Kerk is nie.

In 'n Herderlike Skrywe (1973) het die Kerk hom soos volg oor sy sendingbeleid, onder andere geformuleer in Artikel III van die Kerkwet, uitgespreek:

Waar die kerk in Artikel III dit duidelik uitspreek dat hy integrasie 
op die politiek-maatskaplike gebied verwerp en daarmee by implikasie kies vir afsonderlike ontwikkeling, daar stel'hy teenoor die verwerping van kerklike integrasie baie duidelik en uitgesproke sy beleid van afsonderlike kerke vir afsonderlike volksgroepe. Artikel III is 'n erkenning en aanvaarding van ons kerk se sendingtaak en tegelyk sy sendingbeleid in 'n neutedop. Die artikel is nie net uitdrukking van die verbondenheid van ons kerk aan die Afrikanervolk en sy voorneme om die identiteit van hierdie volk te bewaar en te versterk nie, maar ook uitdrukking van sy verantwoordelikheid ten opsigte van die geestelike heil van die nie-blanke volke met wie hy saam in hierdie land verkeer. Hoewel hy homself nie anders ken dan as kerk vir die Afrikaner nie, wil hy die evangelie nie net vir homself hou nie en die kerk van Christus nie beperk tot hierdie volk alleen nie. Hy wil help dat die een kerk van die Here ook onder ander volke gestalte sal aanneem soos wat dit die geval met die Afrikaner is. Daarom aanvaar hy die verantwoordelikheid vir kerkvorming onder die nie-blanke volksgroepe.

Van groot belang in die formulering van Artikel III is die verwysing na die stigting van ander volkskerke onder die verskillende volksgroepe, waarmee die Kerk dus verklaar dat hy homself ook as volkskerk sien.

Met hierdie siening van homself as volkskerk staan die Nederduitsch Hervormde Kerk vandag bykans alleen in die wêreld. En daaroor word hy meermale ernstig beskimp en verguis. Die Kerk en sy teoloë het al tot vervelens toe aangetoon dat die swaar belastheid van die volkskerkbegrip in verskillende stadiums van die geskiedenis nie die bruikbaarheid van die begrip uitwis nie. In elk geval, die Kerk voel hom nie aangespreek deur die 'sluipende gevaar' van die volkskerk soos $A B$ du Toit dit in Beeld (6 Januarie 1987) skets nie.

Met die koppige vashou aan die siening van homself as volkskerk, wil die Nederduitsch Hervormde Kerk wegkom van die eensydige Piëtistiese beklemtoning van die indiwidu en sy bekering. Hy het as volkskerk in sy gehoorsaamheid tot sending groter liefde en aanvoeling vir die stigting van kerke as eerste oogmerk in sy sendingwerk. Hy het ook die gemeenskap van die gelowiges in die oog, nie alleen die redding van die indiwidu nie. Hy wil as volkskerk ook wegkom van die vrye kerkidee van Kuyper met ongebalanseerde klem op tug en uitverkiesing ten koste van die verbond (Van der Westhuizen 1981: 21). Hy wil in plaas daarvan liewer kies vir 'n benadering van die hele Kerk vir 
die hele volk sonder om te verval in die dwaling waar die grense van volk en kerk saamval. Hy wil as volkskerk hom ook verset teen die gedagte dat om Christen te word, sou beteken om losgeslaan te word van jou volk en kultuur. Hy het eerder in gedagte 'n volkskerk waar die evangelie reformerend kan inwerk op die kulturele lewe van die volk. 'Only when the Gospel itself gave birth to a Church within a particular society, can that Church be the true servant of God and the people it ministers to' (Kommissie van die Algemene Kerkvergadering 1960).

\section{Samevatting}

Die Sinode van die Nederlandse Hervormde Kerk het in 1983 'n studiestuk van sy Raad vir Sending aanvaar onder die opskrif Visie en Werklijkheid. Daarin word dié Kerk se sendingvisie vir die jare wat voorlê, uiteengesit. Die kerk bestaan daarvolgens uit 'n gemeenskap van gestuurdes. Die doelstelling van dié gemeenskap is om mense, met name verdruktes, tot hul reg te laat kom (Meijers 1983: 749). Die aandag van die kerk moet toegespits word op die armes en misdeeldes, op die behoud van menseregte en op die bestryding van diskriminasie, rassisme, seksisme en alle ander vorme van onreg. Om groepe mense mondig te maak, word in die studie gesien as wesenlike opdrag van die Christelike sending.

Hierdie uitspraak verteenwoordig waarskynlik die eindpunt van die proses van verhorisontalisering in die Christelike sending. Dit is die voltooiing van die ekumeniese sendingbenadering van ons tyd waar kerk en sending opgelos word in 'n reaksie op of deelhê aan wat God besig is om in die wêreld en die geskiedenis te doen.

Sewe sinodelede het gevra dat die debat oor die studiestuk heropen moet word omdat die aanvaarding van dié stuk volgens hulle die karakter van die Nederlandse Hervormde Kerk as Christusbelydende volkskerk op die spel plaas (Weekbulletin, 1983: 1). Hulle verklaar verder dat die Bybelse sendingopdrag op onbybelse wyse omgebuig word in liberale sin. Dit beteken 'n breuk met die Reformasie en sal vir die planting en opbou van God se kerk skadelike gevolge hê.

Die wye kloof wat daar vandag in sendingdenke tussen kerke en teologieë bestaan, blyk duidelik as ons teenoor hierdie uitsprake van die Nederlandse Hervormde Kerk nogeens die uitspraak van die Nederduitsch Hervormde Kerk in sy Herderlike Skrywe van 1973 plaas.

Dis ook nie sonder betekenis dat ons kerk sy missionêre taak uitsluitlik verstaan as 'n verkondigingstaak waardeur hy alle 
mense volgelinge en leerlinge van Jesus Christus wil maak nie. Omdat die bediening van die versoening aan die kerk opgedra is, wil ons kerk alleen Christus die gekruisigde verkondig in die uitvoering van sy sendingtaak. Met die besondere beklemtoning van die Woordverkondiging wil ons kerk met alle beslistheid sekere heersende misverstande oor die betekenis van die versoening en die geregtigheid van God wat daarin geopenbaar word, afwys en hom ook met alle mag tot sy beskikking verset teen sekere konklusies wat uit die misverstande getrek word. Die misverstande is eerstens dat die versoeningswerk van Christus al minder verstaan word as verlossing uit die wesenlike menslike nood van sonde en dood, en al meer verklaar word as ' $n$ bevryding uit die tydelike nood op die sosiaal-maatskaplike en die ekonomies-politieke vlak. ' $n$ Verdere misverstand is dat die versoeningswerk op Golgota van so ' $n$ aard is dat dit as 't ware outomaties die eiendom van alle mense geword het. Alle mense is versoen, alle mense is vry, alle mense is gelyk en daarom is die eintlike taak van kerk en wêreld om te verwerklik wat op Golgota 'n feit geword het. ' $n$ Verdere misverstand is dat die primêre taak van die kerk nie meer die verkondiging van die groot heilsdade van God in Christus is nie, maar dat sy taak is om die bevrydingsdaad van Christus deur kerklike aktivisme op die sosiale en die politieke vlak voort te sit. Waar daar nog van verkondiging sprake is, gaan dit nie meer om verbale verkondiging nie, maar om daadverkondiging. Daar word beweer dat die kerk nou lank genoeg gepraat het, sonder sukses en dat dit tyd vir hom geword het om iets te doen. Immers, nie die sielsnood nie, maar die bestaansnood van die moderne mens moet voorrang geniet.

\section{BY 'N KRUISPUNT VAN WEË}

Saam met ander kerke in Suid-Afrika en in die wêreld staan die Nederduitsch Hervormde Kerk voor 'n duidelike kruispunt van verskillende weë in die teologie en veral die kerk se sendingopdrag. Hy sal sy keuse ferm en duidelik moet maak.

Die situasie met betrekking tot die getal nie-Chistene in die wêreld sien tans soos volg daar uit:

In Jesus' time it numbered 250 million. Today with 4,2 billion total population, it is estimated that 2,8 billion are non-Christians - 
eleven times as many non-Christians as when Jesus preached the Sermon on the Mount. By the year 2000 world population will have increased fifty percent and Christians will constitute only fifteen percent of that vast multitude (Conn 1984: 5).

Hoe durf die Kerk terwyl dit die situasie in die wêreld is, sy sendingwerk totaal laat opgaan in 'n verpolitiseerde bemoeienis met die armes?

Dit is nodig dat die Kerk sy sendingopdrag nie biblisisties op enkele Bybeltekste fundeer nie. Maar dit moet nie misgekyk word nie dat die oorheersende klem wat op die ontdekking van breë Bybelse sendingperspektiewe gelê is, die vervaging van die sendingopdrag as verkondiging van die evangelie aan heidene, verhaas het.

Die Kerk moet onverwyld nuwe sendingvelde identifiseer en aan die gang kom met die volgende skof op sy sendingweg. Die Kerk kan in die uitvoering van sy sendingopdrag nie volstaan met geldelike hulp aan 'n sendingkerk wat reeds selfstandig is nie. Dié Kerk, die Hervormde Kerk in Suidelike Afrika, moet nou immers self by sy sendingopdrag uitkom.

Die Kerk moet deeglik oorweeg of hy hierdie nuwe skof met die konsepte en gereedskap uit die verlede wil aanpak: Artikel III; die volkskerk, 'n skeiding tussen sy werk in sending en evangelisasie; sending liewer as dialoog ten opsigte van die nie-Christelike godsdienste; verkondiging liewer as hulp aan verdruktes; die prediking van die versoening in Jesus Christus liewer as hulp op die pad na mondigheid.

Die Kerk moet al dié ou konsepte toets en opnuut teologies deurdink voordat hy dit as waardeloos verruil of weggooi. Doen hy dit op ondeurdagte wyse, sal hy hom, soos soveel ander kerke vandag, die stigma op die hals haal dat hy 'n naprater en naloper van die politiek geword het eerder as van die Woord.

\section{Literatuurverwysings}

BAVINCK, JH 1954. Inleiding in de Zendingwetenschap. Kampen: Kok.

BOSCH, DJ 1979. Heil vir die wêreld. Pretoria: NG Kerkboekhandel.

BOSCH, DJ 1986. Sending: 'n Prinsipiële besinning. In die Skriflig 20/79, 2-14.

BOTHA, SJ 1987. Geskiedenis van die Sendingkerk. Almanak en Bybelse Dagboek. Nederduitsch Hervormde Kerk van Afrika 81, 20-26.

CONN, HM 1984. Missions and our present moment in history. RES Missions Conference, Chicago 1984, 5-18.

DU TOIT, AB 1987. 'n Sluipende gevaar: Wil van God moet nie met dié van volk verwar word, Beeld 6 Januarie 1986, bl 8.

DREYER, Joh [1951] 1978. ' $n$ Toespraak oor die evangelisering van nie-blankes, in Van Wyk 1978: $147-150$. 
DREYER, PS [1959] 1978. Die ontwerp van 'n sendingbeleid, in Van Wyk 1978: 164-175.

DREYER, PS [1961] 1978. Dis tyd om te handel, in Van Wyk 1978: 179-182.

DREYER, PS [1964] 1978. Die kerstening van die heidene, in Van Wyk 1978: 182-185.

GLASSER, AF \& MC GAVRAN, A 1983. Contemporary theologies of mission. Grand Rapids, Michigan: Baker Book House.

KOMMISSIE VAN DIE ALGEMENE KERKVERGADERING, 1960. Memorandum aan die Wêreldraad van Kerke, in Van Wyk 1978: 195-211.

KOMMISSIE VAN DIE ALGEMENE KERKVERGADERING [1973] 1978. Herderlike Skrywe 1973, in Van Wyk 1978: 264-272.

MEIJERS, $S$ 1983. Zending waarheen? De Waarheidsvriend 71/49, 749-750.

NEDERDUITSCH HERVORMDE KERK VAN AFRIKA. ALGEMENE KERKVERGADERING 1945. Notule van die Algemene Kerkvergadering 1945. Argief van die Nederduitsch Hervormde Kerk, Pretoria.

NEDERDUITSCH HERVORMDE KERK VAN AFRIKA. ALGEMENE KERKVERGADERING 1976. Christelike verantwoordelikheid en menseverhoudings in Suid-Afrika, in Van Wyk 1978: 273-279.

PAUW, CM 1986. Nog eens: 'Ruimte vir die sendingwetenskap in ons teologiese studies', in Du Preez, J, Pauw, CM en Robinson, PJ, Sendinggenade: Feesbundel vir WJ van der Merwe. Bloemfontein: NG Sendinguitgewers.

VAN DER MERWE, PJ s a a. Inleiding in die Godsdiens- en Sendingwetenskap. Ongepubliseerde kemaantekeninge. Fakulteit Teologie (Afd A), Universiteit van Pretoria.

VAN DER MERWE, PJ s a b. Sendingteorie C. Ongepubliseerde studiegids. Fakulteit Teologie (Afd A), Universiteit van Pretoria.

VAN DER WESTHUIZEN, HG 1969. Die aanvanklike houding van die Nederduitsch Hervormde Kerk ten opsigte van sending histories-krities nagegaan. DD-proefskrif, Universiteit van Pretoria.

VAN DER WESTHUIZEN, HG 1981. Volkskerk en sending. Pretoria: KITAL.

VAN TONDER, JAP 1987. Die praktyk van die Hervormde Kerk in Suidelike Afrika, Almanak en Bybelse Dagboek. Nederduitsch Hervormde Kerk van Afrika 81, 35-47.

VAN WYK, DJC (red) 1978. Stemme uit die verlede, I: Volkereverhoudings in Suid-Afrika. Pretoria: HAUM.

VAN WXK, DJC 1986. Die Nederduitsch Hervormde Kerk se sendingwerk 1928-1967: Van besinning tot daad. HTS 42, 600-623.

VAN WYK, DJC 1986. Sendingteologiese ontwikkelinge na 1961. Ongepubliseerde studiegids. Fakulteit Teologie (Afd A), Universiteit van Pretoria.

VAN ZYL, FJ [1954] 1978. Die stand van ons sendingwerk in Natal, in Van Wyk 1978: $159-160$.

VAN ZYL, FJ 1960-1978. Sendingwetenskap I: Die apostolaat van die kerk. Ongepubliseerde klasaantekeninge. Fakulteit Teologie (Afd A), Universiteit van Pretoria.

VERKUYL, J 1975. Inleiding in de nieuwere Zendingswetenschap. Kampen: Kok.

WEEKBULLETIN VAN DIE NEDERLANDSE HERVORMDE KERK 39/48, 1983, bl 1-2.

WOLMARANS, HP 1955-1958. Kolleges in Sendingwetenskap. Ongepubliseerde klasaantekeninge. Fakulteit Teologie (Afd A), Universiteit van Pretoria. 